\title{
Reference
}

Brown, M. 1973: The definition of metatexis, diatexis and migmatite. Proc. Geol. Ass. 84, 371-382.

Department of Geology \& Physical Sciences, Oxford Polytechnic, Headington, Oxford $O X 3 O B P$,

U.K.

\section{The polyphase nature and internal structure of the Qôrqut Granite Complex east of Ümánap suvdlua, Godthåbsfjord, southern West Greenland}

\section{Michael Brown and C. R. L. Friend}

Fieldwork during 1979 enables us to describe the internal structure of the Qôrqut granite (McGregor, 1973) in the area to the east of Ümánap suvdlua (fig. 27) and to elucidate the polyphase nature of the magmatism. As a result, it is proposed that future reference be made to the Qôrqut Granite Complex rather than to the Qôrqut granite; this proposal is justified below.

\section{The polyphase nature of the Qôrqut Granite Complex}

The Qôrqut Granite Complex is comprised of a number of different phases and at many localities the relationships between these phases are complex. We divide the phases into three main groups:

(1) leucocratic granites, often characterised by the presence of biotite schlieren and lamellae;

(2) essentially homogeneous, grey biotite granites;

(3) composite aplogranite - granite pegmatite sheets.

\section{Leucocratic granites}

The earliest component of the Qôrqut Granite Complex is the group of leucocratic granites, members of which are particularly well displayed along the coast and slopes of Qôrqut and along the east coast of Ümánap suvdlua. These granites are generally coarse grained with a hypidiomorphic granular texture and vary from massive, homogeneous leucogranites, through leucogranites with biotite lamellae spaced from over $50 \mathrm{~cm}$ to under $10 \mathrm{~cm}$ apart, to inhomogeneous biotite granites with schlieren structure and within which relict gneissose structures (but not textures) are preserved. The latter are considered to be diatexites resulting from extensive anatexis of gneiss (Brown \& Friend, this report). Around Ujarã, ghost-like remnants of gneiss, produced by varying degrees of anatexis and resultant disrup- 


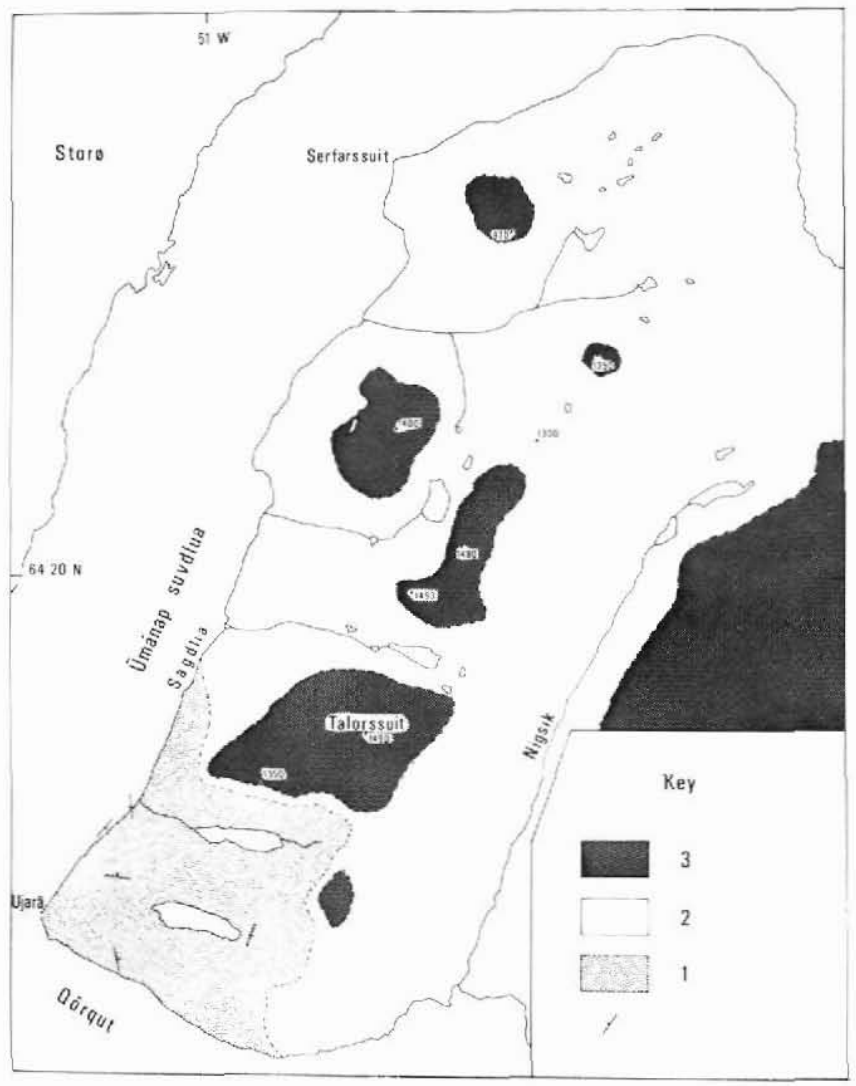

Fig. 27. Locality map showing: (1) lower zone comprising dominantly polyphase granite, (2) intermediate zone consisting of enclaves of country rock contained within sheets of polyphase granite, and (3) upper zone comprising dominantly country rock sheeted by granite. Bar and tick denote orientation and direction of dip of layering in the lower zone.

tion, occur as enclaves and schlieren-trails in the inhomogeneous biotite granites. Elsewhere, occasional rafts and enclaves of essentially unmodified gneiss occur which appear to have retained their original orientation; these are considered to be of local derivation.

\section{Grey biotite granites}

The second component of the complex consists of the group of essentially homogeneous, grey biotite granites. Members of this group occur as sheets from under $1 \mathrm{~m}$ to some tens of metres in thickness which cut both the leucocratic granites and the country rocks. These granites are generally medium grained with a hypidiomorphic granular texture. At many localities (e.g. around Serfarssuit) up to four penecontemporaneous phases of grey biotite granite occur which are distinguished by minor variations in modal mineralogy, mineral colour and grain size. A consistent intrusive sequence occurs at some localities, but it has not proved possible to construct an intrusive sequence applicable to the whole outcrop of this group. Locally throughout the area the grey biotite granites exhibit an interesting textural variant in which felsic (plagioclase \pm quartz) haloes surround cores commonly of euhedral 
magnetite, less commonly of biotite + magnetite or biotite alone, and rarely of euhedral sphene. Where enclaves and rafts of country rocks occur in granites of this group they appear to be essentially unmodified, in marked contrast to many of the enclaves in the leucocratic granites.

Commonly, at contacts between the grey biotite granites and the leucocratic granites the latter are found as balled-up inclusions within the former or there is some interfingering of the two, the leucocratic granites having lobate margins against the grey biotite granites. These features suggest that, at least locally, the leucocratic granites were close to or above their solidus temperatures during the emplacement of the grey biotite granites. Elsewhere, variously shaped xenoliths of the homogeneous leucogranite are contained within members of the grey biotite granite group. At some localities (e.g. on either side of Qôrqut and around Sagdlia) layering occurs both as a result of sheets of biotite granite intimately intruding the leucocratic granites and as a result of biotite concentration. The orientation of this layering is indicated in fig. 27.

\section{Composite aplogranite - granite pegmatite sheets}

The third component of the complex comprises the group of composite aplogranite granite pegmatite sheets which are strongly discordant to the layering described above. Although these sheets are ubiquitous throughout the complex in this area, they are concentrated into the highest zone of the overall structure. Later pegmatite and rare tonalite sheets also occur (Burwell \& Friend, 1979).

\section{The internal structure of the Qôrqut Granite Complex}

In this area the complex comprises three zones (figs $27 \& 28$ ). A lower zone, consisting for the most part of polyphase granite, crops out in the south and is well exposed along Qôrqut and as far north as Sagdlia, along the coast of Ũmánap suvdlua, and the lower slopes of Talorssuit (fig. 27). This zone is dominated by leucocratic granites which are intruded by sub-concordant sheets of various grey biotite granites; both are cut by strongly discordant composite aplogranite - granite pegmatite sheets (fig. 28). Enclaves of unmodified country rocks are rare within this zone.

In the central part of the area an upper zone is exposed in a series of mountain peaks (e.g. the $1493 \mathrm{~m}$ mountain, fig. 27); this corresponds to the roof zone of Burwell \& Friend (1979). Here, the country rocks, mainly Amîtsoq gneisses, are cut by interconnected sheets of grey biotite granite and both are cut by anastamosing composite aplogranite - granite pegmatite sheets (fig. 28). The essential characteristic of this zone is that the country rocks are dominant over the granites.

These two zones are separated by one outcropping at low and intermediate heights throughout the central and northern parts of the area (e.g. the slopes east of Serfarssuit, fig. 27) within which the grey biotite granites form the dominant component of the complex. The internal structure of this zone comprises horizons of polyphase granite with abundant rafts and enclaves of essentially unmodified country rocks, both Amitsoq gneisses and post-Amîtsoq rocks, separated by sheet-like bodies of polyphase granite devoid of enclaves (fig. 28). Granites make up between one-half and two-thirds of this zone. 


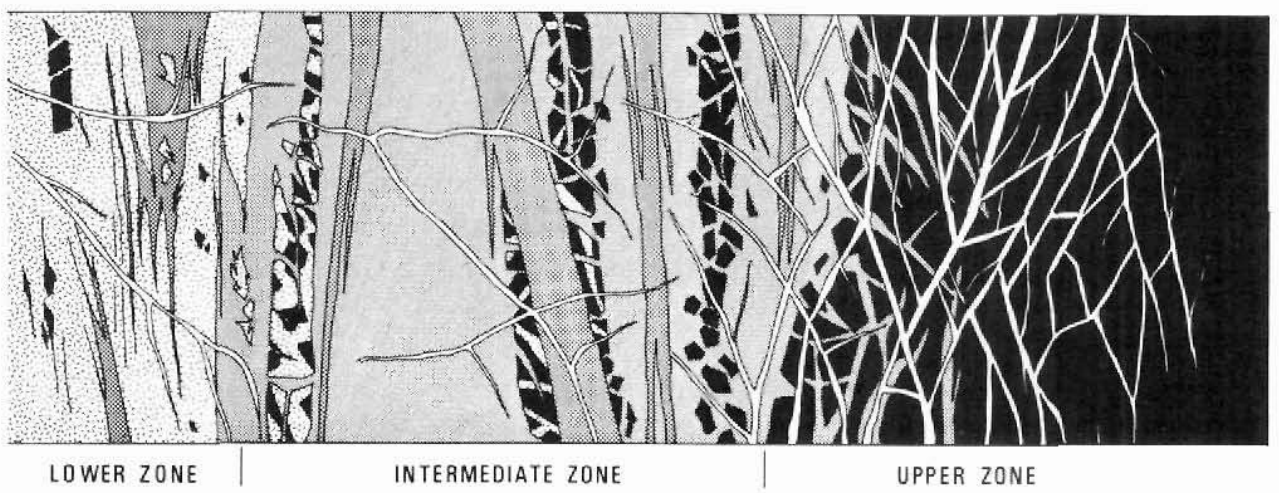

Fig. 28. Schematic section through the Qôrqut Granite Complex showing the division into three zones. The section represents a height of about $1500 \mathrm{~m}$ from left (lower zone) to right (upper zone). See text for explanation.

\section{Conclusions}

We have shown that the late Archaean Qôrqut granite in this area is comprised of a polyphase sequence of granites which we divide into three main groups. The leucocratic granites, often characterised by biotite schlieren and lamellae, have not been reported previously. The essentially homogeneous, grey biotite granites correlate with the "grey phase richer in biotite" of Bridgwater et al. (1976, p. 62) and the composite aplogranite granite pegmatite sheets to their "paler, coarser grained phase". In addition, the Qôrqut granite here exhibits a distinct vertical structure divisible into three zones. These are: a lower zone dominantly of granite; an intermediate zone with a substantial proportion of country rock as rafts and enclaves in granite and with a complex sheeted structure; and an upper zone dominantly of country rock sheeted by granite. Although the internal structure of the granite has not previously been recorded explicitly, the intermediate zone and the upper zone respectively correspond to "the main body of the intrusion" and "the roof zone" of Burwell \& Friend (1979).

In the light of these observations we propose that the term Qôrqut Granite Complex be used instead of Qôrqut granite since the latter term suggests a discrete plutonic body.

The geochemistry of the Qôrqut Granite Complex in this area is currently the subject of a post-granduate study by W. T. Perkins at Oxford Polytechnic.

\section{Acknowledgements}

We thank A. D. M. Burwell, V. R. McGregor and C. G. Topley for reading the manuscript.

\section{References}

Bridgwater, D., Keto, L., McGregor, V. R. \& Myers, J. S. 1976: Archaean gneiss complex of Greenland. In Escher, A. \& Watt, W. S. (edit.) Geology of Greenland, 18-75. Copenhagen: Geol. Surv. Greenland. 
Burwell, A. D. M. \& Friend, C. R. L. 1979: Observations on the late Archaean Qôrqut Granite, Qôrqut, Godthåbsfjord, southern West Greenland. Rapp. Grønlands geol. Unders. 95, 76-79.

Department of Geology \& Physical Sciences, Oxford Polytechnic, Headington, Oxford $O X 3 O B P$,

U.K.

\title{
The South Greenland uranium exploration project
}

\author{
Ashlyn Armour-Brown, Tapani Tukiainen and Bjarne Wallin
}

The SYDURAN project completed the airborne gamma-spectrometer and geochemical sampling survey over some $14000 \mathrm{~km}^{2}$ of south-west Greenland from the fjord Sermiligârssuk in the north-west to Kap Farvel in the south and up the east coast as far as the southern shore of Lindenows Fjord. This covered all the Ketilidian structural zones and a small area of Archaean as classified by Allaart (1976) (fig. 29). Geological field work and prospecting of a more detailed nature was carried out in five areas where previous work indicated possible uranium mineralisation.

\section{Geological reconnaissance}

Due to the well known association of uranium mineralisation with Proterozoic rocks and alkaline rocks, the Proterozoic supracrustal units and the Gardar suite of alkaline rocks were selected as having a greater uranium potential and warranting more detailed investigation.

There are two areas which contain Proterozoic supracrustal rocks in south-west Greenland: (1) in the Border Zone and (2) in the Folded Migmatite Zone and the Flat-lying Migmatite Complex in the south. The exploration of the supracrustal rock units in the Border Zone gave negative results. Their radioactivity is uniformly very low and no radioactive mineralisation was discovered. The extensive supracrustal units in the Folded Migmatite Zone containing migmatised arenite and pelite, on the other hand, have two or three times the radioactive background of the supracrustal units of the same lithology in the Border Zone. Numerous small radioactive mineralisations were found in the granitic and pegmatitic neosomes in the migmatite, often in the form of secondary uranium minerals, which indicates that the uranium is in an available form. These results alone show that the supracrustal units in the Folded Migmatite Zone may contain economic amounts of uranium and should be further investigated.

This season's geological reconnaissance was mainly carried out in the Gardar alkaline complexes and their surroundings (for pre-1976 references see Emeleus et al., 1976). The Nunarssuit, Puklen, Tugtutôq, Narssaq and Qagssiarssuk complexes gave meagre results. Radioactive pegmatites are common throughout the entire Nunarssuit complex but these and the more radioactive localities within them are scattered and insignificant. Only occasi- 